\title{
The Influence of the Roman Catholic Church on Midwifery Practice in Malta
}

\author{
C SAVONA-VENTURA*
}

Advances in scientific thought, including those in medicine, have greatly affected the whole of human life and continue to have a stupendous impact on it. Contemporary medicine bears a tremendous responsibility for the well-being of all humankind, one which is shared with other disciplines including religion. Throughout the centuries the Roman Catholic Church has provided strong guidance during times of moral disorientation. But its contribution in the fields of bioethics is likely to evoke an ambivalent reaction, since the ecclesiastical authorities often appear to repeat the same old moral principles, drawing the same old moral conclusions without engaging in convincing moral reasoning. The Roman Catholic Church believes that there is the need for a humble meeting of religion and modern science on current problems, while at the same time it sees itself as the guardian of God's Word from which it draws religious and moral principles without always having at hand the solution to particular problems.

The conflicts created by the Church's teachings vis-à-vis scientific advances and society's expectations have been strongly felt in a small traditionally Roman Catholic community like the Maltese Islands. These conflicts, particularly in issues related to reproduction, have throughout the centuries resulted in efforts by the ecclesiastical authorities in Malta to control medical matters. Only $93 \mathrm{~km}$ away from Sicily and 290 $\mathrm{km}$ from the northern coast of Africa, the Maltese group of islands occupies a central position in the Mediterranean, which made them an important meeting place for the various Mediterranean cultures. Christianity was brought to the islands by the apostles Paul and Luke in about $60 \mathrm{AD},{ }^{1}$ and the arrival of the Normans in 1127 AD resulted in a cultural and political connection with Sicily during the Middle Ages, which strengthened the Church's dominance. Its influence was further augmented when in 1530 the Emperor Charles V of Spain ceded the Maltese Islands to the Knights Hospitallers of St John of Jerusalem, who continued to rule until they were expelled by Napoleon Bonaparte in 1798. The traditionally Catholic matrix of the Maltese population allowed the strong authority of the Roman Catholic Church to persist even during the nineteenth and first half of the twentieth century when the Islands fell under the administration of Protestant England, and Anglican ecclesiastics repeatedly attempted to establish their influence on the colony. ${ }^{2}$

The Roman Catholic Church on the Maltese Islands set up institutions for social and charitable purposes such as protecting the oppressed, helping the needy and tending the

*C Savona-Ventura, MD, MRCOG, Department of Obstetrics and Gynaecology, St Luke's Hospital, G'mangia, Malta.

1 St Luke, Acts of the Apostles, 28:1-10.
${ }^{2}$ A Bonnici, History of the church in Malta: period IV: 1800-1975, Malta, Catholic Institute, 1975, vol. 3, pp. 187-202. The first attempts towards proselytism in Malta date to 1809 when members of the Bible Society of London distributed copies of an 


\section{The Roman Catholic Church and Midwifery Practice in Malta}

sick. The first recorded move of the Church authorities in the field of medicine was the establishment of hospitals such as the Hospital of St Francis, later the Santo Spirito Hospital, which by 1372 was functioning under the rectorship of a Franciscan, Niccolò Papalla, appointed by the King of Sicily. Though a change in the hospital's administration was made in 1433 , it remained under the jurisdiction of the bishop. The hospital cared mainly for those too old, or too poor, or otherwise incapable of caring for themselves, but also took in foundlings and sick people. It is known to have contributed to the maternity services of Malta during the late eighteenth and early nineteenth centuries. A number of religious-managed maternity hospitals were organized in the twentieth century. ${ }^{3}$

\section{Reproductive Practices in Malta}

Little is known about reproductive practices on Malta prior to the sixteenth century. At that time, women were reported to commence their reproductive life at the age of twelve, a fact which is apparently confirmed by archaeological records. ${ }^{4}$ In 1528 the Maltese population allegedly numbered 17,000 , but the baptismal records of the latter part of the sixteenth century suggest significantly higher birth rates and the population had increased to 28,864 by 1590 . In 1680 it was estimated to be approximately 50,000 , while by 1797 the figure had risen to 96,534 . At the beginning of the twentieth century (1901) the population numbered 184,742 , and in 1985 had reached $345,418 .^{5}$ Until the twentieth century most deliveries, in common with practice elsewhere in Europe, were conducted in the home under the supervision of a traditional health attendant or a midwife. During the late nineteenth century midwives in Malta were allowed to deal with cases of longitudinal presentations, but were advised to call the medical practitioner in abnormal presentations or cases of prolonged labour. The practitioner's intervention varied according to circumstances and followed the obstetric teaching of the time, resorting to internal version and instrumental deliveries. Hospital confinements were limited to socially necessitous women or difficult cases.

unauthorized edition of the Bible to the local population. In 1814 the Biblical Society of Malta was formed. The Ecclesiastical Authorities repeatedly protested against the activities of Protestant Missionaries to the British Government representative in Malta. The British Governors were advised time and again by the British Authorities to curtail the attempts to protestantize Malta. The first Maltese census in 1842 shows that the number of English residents amounted to 1,161 , of which about 1,000 are presumed to have been Protestants. The number of Protestants in 1909 amounted to 1,350.

${ }^{3}$ S Fiorini, Santo Spirito Hospital at Rabat, Malta: the early years to 1575, Malta, Dept of Information, 1989, pp. 3-11; F Ciappara, Marriage in Malta in the late eighteenth century, Malta, Associated News (M) Ltd, 1988, p. 85; Medical and Health Archives, 'Letter Book', 2 January 1838 to 28 April 1842, fol. 65; Three hospitals managed by religious orders offered maternity services in the
Maltese Islands during the period 1945-1980. These included (1) the Zammit Clapp Hospital in Malta run by the Sisters of the Little Company of Mary (Blue Sisters) 1945-1980; (2) the St Catherine of Siena Hospital in Malta run by the Dominican Sisters 1961-1980; and (3) the Trijonfi Clinic in Gozo also run by the Dominican Sisters 1974-1976.

4 Bibliotheca Vaticana, 'Urbinato Latino', MS. 833, fols. $140 \mathrm{v}-141 \mathrm{p}$, in A Bonnici, Maltin $u l$ Inkizzjoni f'nofs is-seklu sbatax, Malta, K.K.M., 1977, p. 48, note 87; J L Pace and S Ramaswamy, 'Skeletal remains, in Excavations at Hal Millieri, Malta: a report of the 1977 campaign conducted on behalf of the National Museum of Malta and the University of Malta, (eds) T F C Blagg, A Bonanno, A T Luttrell, Malta University Press, 1990, pp. 84-95.

5 B Blouet, The story of Malta, Malta, Progress Press, 1989, pp. 70-4; Census '85, vol. 1, A demographic profile of Malta and Gozo, Malta, Central Office of Statistics, 1986. 


\section{Savona-Ventura}

The first law regulating midwifery in Malta dates from 1624 when midwives were required to obtain a licence to practise midwifery after examination by the Protomedicus or principal medical doctor. This enactment was repeatedly included in various versions of Maltese legislation. By 1899 a set of 'Regulations respecting midwives', had been produced. These laid down detailed instructions for the intrapartum and postpartum care of women. ${ }^{6}$ Prior to the nineteenth century, the apprenticeship method of midwifery training was in force. The formal teaching of midwives was initiated in 1802. During the first half of the nineteenth century, the school of midwifery functioned very erratically and fresh efforts to organize a School of Practical Midwifery were necessary in 1868. In spite of an initial poor response, the school eventually became well established, holding regular courses. ${ }^{7}$ At the end of the nineteenth century, the needs of the pregnant wives of British soldiers stationed in Malta were entrusted to the one or two English midwives who happened to be living there, some having followed the Midwifery Courses held at the Central Hospital in Malta. Following the endeavours of the Governor's wife Lady Sym Fremantle, Professor G B Schembri initiated in 1896 the Military Midwives Class held for English women living on the island. By 1902 twenty-two British women had attended the course and qualified as midwives. ${ }^{8}$

The early attempts by the civil authorities to control the practice of midwifery in Malta contrasts with the situation in the United Kingdom, where, in spite of pressure from a number of individuals for the training and municipal control of midwives, it was only after 1870 that a voluntary examination of proficiency in midwifery was set up. Earlier regulation introduced in the sixteenth century emphasized the moral character and religious affiliation of the midwife rather than her professional competence. The situation was different on the Continent. By the middle of the fifteenth century many cities in Germany, the Netherlands and France had introduced a system of municipal regulation whereby midwives were formally examined regarding their technical competence by physicians and/or experienced midwives. In 1770 because of growing apprehension of a fall in the French population, the King's physician Joseph Raulin was commissioned by the French government to publish a book for the instruction of midwives, while an eminent midwife, Madame du Coudray, was sent to tour the provinces to lecture midwives and organize the establishment of lying-in hospitals. After the Revolution in 1803 a comprehensive national system of medical regulation was set up to improve the practice of midwifery in the country. In the Netherlands, during the French occupation in 1795 , enactments affecting midwifery practice were passed, which were re-organized in $1818 .^{9}$

${ }^{6} \mathrm{~S}$ L Pisani, Ktieb il qabla, Malta, P Debono, 1883, pp. 100-2; 'Regulations respecting midwives', Malta Government Gazette, 7 August 1899, p. 774; C Savona-Ventura, 'Control of midwifery: historical perspectives', Midwives Journal, in press.

${ }^{7}$ National Malta Library, MS. 2, fol. 601; P Cassar, Medical history of Malta, London, Wellcome Historical Medical Library, 1964, p. 412-14; SavonaVentura, ibid.

${ }^{8}$ Medical and Health Archives, 'Register of References to Comptroller of Charitable Institutions', vol. 1, fol. 78; G B Schembri, The midwife's guide book, Malta, Govn. Printing Office, 1896, preface;
Medical and Health Archives, 'Letters to Government, 10 April 1895 to 31 March 1903', fols. $100,185,414$. In 1908 the total number of births in military families numbered 196. 'General health report', Malta Government Gazette, 26 November 1909, 5214(suppl): 1 .

9 J M Munro Kerr, R W Johnstone, and M H Phillips (eds), Historical review of British obstetrics and gynaecology 1800-1950, Edinburgh, Livingstone, 1954, pp. 334-6; J Donnison, Midwives and medical men: a history of inter-professional rivalries and women's rights, London, Heinemann Educational Books, 1977, pp. 40-1; M J van Leiburg 


\section{The Roman Catholic Church and Midwifery Practice in Malta}

\section{Episcopal Licencing}

Church Courts exercised jurisdiction over a wide range of human affairs. The ecclesiastical authorities in Malta had influenced midwifery practices prior to state legislation and control. Church control was introduced mainly to ensure the baptism of newborn infants who were likely to die soon after birth. The concern of the Roman Catholic authorities with such baptisms reflected the controversy over the fate of the souls of the unbaptised infants. While the existence of the limbo of infants had never been clearly defined by the Church, it was an inevitable conclusion based on the statement that "unless a man be born again of water and the Holy Ghost, he cannot enter into the kingdom of God" (John 3:5). Some Doctors of the Church, such as St Augustine and St Gregory the Great, maintained that unbaptised infants were damned however light their suffering might be. Others believed that these souls, detained in a limbo of infants, were in a state of purely natural happiness and knew nothing of heaven which was closed to them for ever. It was in recent decades that Catholic theologians re-examined the question and proposed that unbaptised infants' souls go straight to heaven. ${ }^{10}$

The Apostolic Delegate and Visitor-General to Malta, Mgr. Pietro Duzina (1574-1575), enjoined parish priests to teach midwives the proper administration of baptism in casu necessitatis. He also condemned procrastination in the administration of the sacrament. These admonitions were repeated by the Maltese Synod of 1625 convoked by Bishop Balthassar Cagliares (1615-1635). The Synod convoked by Bishop David Cocco Palmieri (1684-1711) in 1703 laid down that midwives were to be examined by their parish priests at least twice a year, on the octave of Pentecost and Christmas. ${ }^{11}$ The pastoral visit of Archbishop Paulus Alpheran de Bussan (1728-1758) in 1744-1751 records that if midwives were not found sufficiently versed in the administration of the sacrament of baptism, the parish priest was to instruct them, during which time they were precluded from practising. Examinations were repeated whenever the bishop or vicar paid a pastoral visit to the parish. On such an occasion, the midwives submitted for inspection and renewal by the bishop the warrant of the Protomedicus and the licence of the Episcopal Curia. Midwives took an oath to exercise their profession with "charity and diligence". Fr Arcangelo Farrugia, parish priest of a rural village in Malta, testified in 1798 that Maria Calleja was an honest woman, and she answered satisfactorily questions put to her about the rites of baptism, abortions, and Caesarean sections. Yet this rigorous control of the training of midwives in the administration of baptism was not entirely effective. On 11 October 1794, Archbishop Vincenzo Labini (1780-1807) "having been notified of the irregular manner with which midwives often christen children in difficult deliveries, not so much because of their inexperience, but because of the confusion in which in such circumstances they found themselves" instructed all parish priests that in

and $\mathrm{H}$ Marland, 'Midwife regulation, education, and practice in the Netherlands during the nineteenth century, Med. Hist., 1989, 33: 296-317; R L Petrelli, 'The regulation of French midwifery during the ancien regime', J. Hist. Med., 1971, 26: 276-91; H Marland (ed.), The art of midwifery: early modern midwives in Europe, London, Routledge, 1993.

${ }^{10}$ M Quin, Virtue's Catholic Encyclopedia,

\footnotetext{
11 National Malta Library, MS. 643, fol. 589; Costitutiones in diocesana synodo melivetana, Rome, 1625; Synodus diocesana Fr. David Cocco Palmieri, Rome, 1709, p. 26; A Bonnici, History of the church in Malta: period III, 1530-1800, Malta, Catholic Institute, 1968, vol. 2, pp. 19-24, 51.
} 


\section{Savona-Ventura}

order to correct such an abuse which could be the "cause of the eternal loss of so many poor souls", they were to rebaptise babies sub conditione in the presence of two witnesses. $^{12}$

The preoccupation of the archbishop with the loss of souls is understandable in the light of Roman Catholic beliefs relating to the salvation of souls and the high mortality rate of newborn babies at the time. Neonatal deaths buried in the first month of life in a rural Maltese village during 1750-1789 amounted to approximately 163 per 1,000 registered baptisms, while infant deaths amounted to 281 per 1,000 baptisms. The number of stillborn children is difficult to ascertain since they were rarely indicated in the parish registers, but those who died within a few hours of their birth amounted to 30.4 per cent of infant deaths. Privately baptised infants amounted to 2.4 per cent of total burials in the village. In the late nineteenth century, infant mortality remained high while neonatal mortality showed a marked improvement, possibly as a result of the advances made in midwifery practice during this century. Thus in 1895 the infant mortality rate amounted to 229 per 1,000 births, while stillbirths and the neonatal mortality rate amounted to 25.7 and 33.0 per 1,000 births respectively. These figures were maintained until the midtwentieth century. ${ }^{13}$

The concern over the administration of baptism to dead newborn infants is further reflected in S L Pisani's notes of lectures given to prospective Maltese midwives in 1883, and published in the vernacular. He instructed the midwives to administer the sacrament of baptism in all cases of fetal or neonatal death and conditionally even in all cases of miscarriage. Similar instructions were given in 1897 by G B Schembri in his lecture notes to Maltese student midwives, though they were omitted from those aimed at British student midwives. ${ }^{14}$ This belief in the necessity for early baptism persisted well into the twentieth century. A licence from the Maltese Episcopal Curia remained a requirement to practise midwifery until 1906. Information booklets about pregnancy and childbirth published in the 1960s directed Maltese mothers to arrange their infants' baptisms soon after birth and also included instructions on immediate baptism in cases of impending neonatal death. ${ }^{15}$

The Church authorities' anxiety over timely baptism in order to save the infant's soul was not solely a Maltese issue. It was considered important in other European countries too. In fourteenth-century England, parish priests were enjoined to command any midwife who "lost a chylde, bothe soule and lyfe that she shulde no more come eftesones where chyldryn were bore". By the middle of the fifteenth century the regulation of midwives on the Continent was no longer being left solely to the Church. Municipal authorities, particularly in Germany and the Netherlands, started showing concern for the

\footnotetext{
12 Archiepiscopal Archives Melitensis, MS. 190, 'Pastoralia (1744)', fols. 5t, 112, 375 hereafter AAM); AAM, VP, vol. XLI, fol. 100r; Curiae Episcopal Melitensis, AO693, fols. 115r-125v (hereafter CEM); AAM, Corr. XXIII, fol. 268r; Parish Archives (Zejtun), Lib. Bapt. X, unnumbered.

13 Parish Archives (Naxxar), Lib. Def. II, (1687-1761), III (1762-1810); Ciappara, op. cit., note 3 above, pp. 106-7; S L Pisani, 'Return of deaths in Malta and Gozo', Malta Government Gazette, 1895-1896 fortnightly reports, nos. 3738-3794.
}

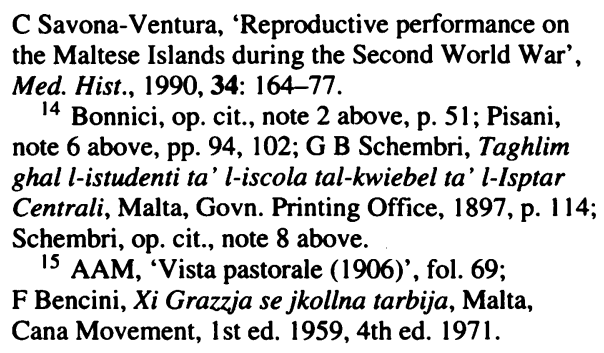

C Savona-Ventura, 'Reproductive performance on the Maltese Islands during the Second World War', Med. Hist., 1990, 34: 164-77.

14 Bonnici, op. cit., note 2 above, p. 51; Pisani, note 6 above, pp. 94, 102; G B Schembri, Taghlim ghal l-istudenti ta' l-iscola tal-kwiebel ta' l-Isptar Centrali, Malta, Govn. Printing Office, 1897, p. 114; Schembri, op. cit., note 8 above.

15 AAM, 'Vista pastorale (1906)', fol. 69; F Bencini, Xi Grazzja se jkollna tarbija, Malta, Cana Movement, 1st ed. 1959, 4th ed. 1971. 
health of their communities, and midwives were beginning to be examined for their technical competence. But in France, where the Catholic Church remained the principal religious communion, as late as the eighteenth century the most important criterion in the selection of a midwife- - outside of Paris and one or two of the larger provincial townswas still that she should be a good Catholic, capable of administering the sacrament of baptism when required. Interest in her obstetric knowledge remained minimal. In England the first formal arrangements for midwifery control were made in 1512, but the responsibility for its implementation was given to the ecclesiastical authorities, who continued to hold this power even after Henry VIII's break with Rome in 1534. Midwives were therefore required to apply to the Bishop's Court and, if granted a licence, to take a solemn oath swearing to obey the rules of conduct which the Church laid down. Any midwife who worked without a licence ran the risk of being reported to the Bishop's Court and prohibited from practice, as well as being made to do penance, or even excommunicated. By the seventeenth century, municipal regulation of midwives was common on the Continent, but licensing in England remained under ecclesiastical control. Edinburgh followed the continental example of municipal licensing in 1694. The British system of ecclesiastical licensing ceased to operate as the power of the Church waned in the eighteenth century and the man-midwife began to emerge. ${ }^{16}$

\section{Post-mortem Caesarean Section}

The requirement of baptism for the salvation of souls created problems in cases of mothers dying undelivered. Efforts were to be made at all costs to deliver the child so that it could be baptised and its soul saved. For the Catholic Church this was a long established policy dating from 1280 when post-mortem Caesarean section was ruled to be obligatory. A fifteenth-century British manual outlining the duties of the parish priest advises "And 3ef the wommon thenne dye, teche the mydwyf that scho hye for to undo hyre wyth a knyf and for to save the chyldes lyf and hye that hyt crystened be, for that ys a dede of charyte". The Venetian Republic made post-mortem section a legal requirement in 1608 , while the Kingdom of Sicily made similar provisions in $1749 .{ }^{17}$ On 14 June 1788, the Maltese Archbishop Labini published an edict enforcing the obligation to perform post-mortem Caesarean section "and thus endeavour, if possible, to save the temporal existence of the fetus or at least its spiritual life which is more important". Parishioners were ordered on pain of excommunication to inform parish priests of pregnant women who were in danger of dying. Those who provided such information, or helped in any way, were granted an indulgence of forty days. Parish priests were to ensure that a Caesarean section was performed by securing the services of "a surgeon or,

\footnotetext{
16 J R Guy, 'The episcopal licensing of physicians, surgeons and midwives', Bull. Hist. Med., 1982, 56: 528-42; Petrelli, op. cit., note 9 above; Donnison, op. cit., note 9 above, pp. 4-22; T R Forbes, 'The regulation of midwives in the sixteenth and seventeenth centuries', Med. Hist., 1964, 8: 235-44; idem, The regulation of midwives in the eighteenth and nineteenth centuries', Med. Hist., 1971, 15: $352-62$.
}

\footnotetext{
17 J Myrc, 'Instructions to parish priests', ed. E Peacock, London, 1902, lines 97-102, in Donnison, op. cit., note 9 above, pp. 2-3; Prammatica Sanzione emanata nel Regno di Sicilia intorno al Parto Cesareo, n.p. 1749; P Cassar, 'The church on Caesarean section in Malta in 1867', St. Luke's Hospital Gazette, 1969, 4(1): 48-52.
} 


\section{Savona-Ventura}

in his absence, a physician, a midwife, a barber or another person who wanted and knew how to carry out" the operation. In the absence of a capable person, the parish priest was obliged to perform it himself and had to ensure that there was at hand "some iron or implement" suitable for the purpose. ${ }^{18}$ In order to obtain and keep their Episcopal Curia licences, it was an essential requirement for eighteenth-century midwives to have the medical knowledge to carry out a Caesarean section. ${ }^{19}$

The first documented post-mortem Caesarean section in Malta was performed on 13 December 1780 on an eight-month pregnant woman who had died from malignant fever. The assistant surgeon had been sent to the quarantine hospital two days earlier to be in readiness "to open the body in the event of the patient's death and save the baby if possible". The infant was born alive but died after an hour, presumably after being duly baptised. Dr F Butigiec in his midwifery lectures to medical students urged them not to neglect to perform the operation and reminded them of the injunctions of the Church, and especially those of Pope Gregory IX, St Thomas Aquinas, and St Charles Borromeo, besides quoting extracts from the edict of 9 August 1748 of King Ferdinand IV of Sicily on the matter. Live mothers requiring operative interventions to enable delivery were to be exhorted by the appeals of their spiritual director to their conscience to undergo Caesarean section in the hope that a live infant could be delivered which could be baptised.

The early nineteenth century furnishes further examples of post-mortem sections being performed by various practitioners with the aim of baptising the infant. There are no definite cases recorded where the operation was performed by a non-medical person, though it was reported in 1867 that there were curates and midwives who carried out the operation successfully in accordance with the rules of the surgical art. ${ }^{20}$

A controversy arose during the cholera epidemic which affected the Maltese Islands in July 1867 . A police physician practising in the Islands' capital refused to perform a postmortem Caesarean section on a pregnant woman who had died from cholera, because he adhered to a school of thought which held that in cholera cases the fetus pre-deceased the mother. This view was supported by the Principal Police Medical Officer. As a consequence, Archbishop Gaetano Pace Forno (1857-1875) felt the need to warn a police physician in a rural village on Malta not to fail to perform post-mortem sections should the need arise, and furthermore issued a circular to parish priests in which he reminded them that it was their duty to order medical practitioners to perform Caesarean operations whenever necessary so that no opportunity was lost of saving the offspring, or at least of ensuring that it received baptism. He also reiterated that when no physician was willing to perform the operation, the clergy were bound to call in a midwife or another expert person, or to perform it themselves. The Archbishop's decree gave rise to a dispute which was hotly debated in the local press. The Malta Times criticized the Archbishop's decree on grounds of the unreliability of a non-professional's judgement in

18 AAM, 'Edicta Labini', vol. 12, fol. 175r; Malta Times, 10 October 1867, p. 2; L'Ordine, 11 October 1867, p. 3.

19 CEM, AO693, op. cit., note 12 above.

20 F Butigiec, 'Trattato dell' arte ostetrica dettato e spiegato del Perille Signor Dr Francesco Butigiec nello studio publico del Grand Ospedale Nazionale di' Malta. Principiato li 18 Ottobre 1804', manuscript, 1804, in P Cassar, 'Teaching of midwifery in Malta at the beginning of the nineteenth century', St. Luke's Hospital Gazette, 1973, 8(2): 91-111; C Savona-Ventura, 'Caesarean section in the Maltese Islands', Med. Hist., 1993, 37: 37-55; Il Portafolio Maltese, 12 October 1867, p. 2. 
determining whether a person was alive or not and the legality of immediately opening up a corpse, since Maltese law prohibited burials during the twenty-four hours after apparent death. It was not surprising that the newspaper took this view as it was successively edited by Englishmen, and defended British and Protestant interests on the island while opposing Roman Catholicism as the established religion.

Other newspapers generally critical of British interests in Malta, including L'Ordine and Il Portafoglio Maltese, were in favour of the decree and took the medical profession to task. One contributor pressed the government to bring in a law obliging "doctors in all cases of pregnant women, without any exception, to carry out Caesarean section to save the soul and body of a citizen who had the inherent right to live". No legislative measures were introduced by the then Protestant administration, but within a month of the Archbishop's circular three sections were performed, one on a mother dying in the fourth month of pregnancy where "the fetus outlived the mother for seven minutes and received baptism". Another woman believed to be five months pregnant was also operated on but no fetus was found to exist. ${ }^{21}$ Student midwives at the end of the nineteenth century were instructed to be prepared to perform the operation on dead pregnant women in the absence of a doctor. ${ }^{22}$

\section{Monsters and Witchcraft}

The birth and death of a grossly malformed infant or monster also posed an intriguing quandary to the canonists. The officiating priest was enjoined to examine the monster to ascertain that its principal parts, namely the head and chest, had a human configuration. If they did, the infant was baptised, but if the head was that of an animal and the limbs those of a human, the creature was baptised sub conditione si es homo ego te baptizo. A case of the birth of a putrefied malformed fetus was submitted to the Episcopal Court in 1630 by the attending midwife in order to justify its burial in unconsecrated ground without any religious ritual. Another report dated 1788 records the birth of a fetus which was examined by the parish priest who considered it conformed more to human than to an animal and ordered a church burial. ${ }^{23}$

As late as the mid-nineteenth century canonists were still debating the religious issues raised by the birth of monsters. In their conclusions they were swayed by the conviction that these deformed beings were the result of copulation between a woman and a male beast or the devil. The belief was current in Malta during the seventeenth century that consort with the devil in an assumed form was possible. In 1647, a 17-year-old woman accused herself before the Inquisitional Tribunal of having over the previous six years had carnal relations with men and animals brought to her by the devil. She became pregnant and procured an abortion on a number of occasions. In 1676 a Maltese physician's wife accused herself of having invoked the devil and invited him to have

\footnotetext{
${ }^{21}$ Cassar, ibid.; L'Ordine, 4 October 1867, p. 3; L'Ordine, 11 October 1867, p. 3; L'Ordine, 18 October 1867, p. 3; Malta Times, 24 October 1867, p. 1; H Frendo, 'Maltese journalism 1838-1992, 2: censorship abolished', Sunday Times [of Malta], 6 December 1992, pp. 52-3.
}

\footnotetext{
22 Pisani, op. cit., note 6 above, pp. 104-5.

23 CEM, AO508; S Fenech, : 'Report of the birth of a monster with its sketch', Public Records Office Misc. 76, Malta, 1788; P Cassar, 'The birth of monsters in the Maltese Islands in the 17th and 18th centuries', Mediscope, 1983, 1: 6-9.
} 


\section{Savona-Ventura}

sexual intercourse with her if he destroyed her husband. ${ }^{24}$ While the ideas about the origin of monsters changed in subsequent centuries, it was only at the beginning of the twentieth century that the Roman Catholic Church accepted that a woman could not conceive after intercourse with a beast or the devil ${ }^{25}$.

The Church authorities were also on their guard against possible witchcraft by midwives. The umbilical cord, caul, afterbirth, and stillborn fetus played an important part in the rites of witchcraft. Superstitious beliefs relating to childbirth still persist among the Maltese. It is believed that a child born with a caul will become exceptionally strong and invulnerable, while old fishermen believe that a piece of caul protects them from drowning. The umbilical cord is also credited with medicinal properties. These beliefs have similar parallels in the surrounding Mediterranean region. Two midwives are reported to have appeared before the Maltese Ecclesiastical Court to justify their actions during abnormal childbirths. The first, in 1598, was asked to justify her failure to deal with a case of foot presentation, while the second, in 1630 , had to justify the burial of an abnormal child without religious ritual. Healing by sorcery was common during the seventeenth and eighteenth centuries, with a number of cases being brought before the Inquisitional Tribunal. The general trend of the witch hunt in early modern Malta, as in the rest of Europe, was essentially an attack on defenceless members of society who at times were considered a threat to the established system because they did not conform. There were, however, only two main trials in 1617 and 1625 when women suspected of witchcraft were brought to trial en masse. In the first, 32 women were accused, while in the second the number was 40 . The penalties meted out were generally light: the women had to promise to keep silent about the matter, abjure their misdeeds, express contrition, and recite a few prayers for a period of time. This was in marked contrast to the situation elsewhere in Europe. In Paris in 1409 a midwife was "turned" in the pillory and banned from practice for unwittingly supplying a fetus for use in magical rites, while in Germany women were actually executed for witchcraft. ${ }^{26}$

\section{Disease as a Consequence of Sin}

The ecclesiastical concern for the salvation of souls at the point of death was not limited only to newborn babies. The probable death of a pregnant woman required efforts from medical attendants and practitioners to enable spiritual directors to administer the sacraments, thus contributing towards the salvation of that soul by giving sacramental grace. Until the nineteenth century Maltese medical and surgical practitioners were

\footnotetext{
24 Archivum Inquisitionis Melitensis, 'Criminalia 1644-1648' (hereafter AIM); AIM 79, fol. 174.

25 Cassar, op. cit., note 23 above. By the eighteenth century, Maltese physicians held the theory that the phantasy organ of a pregnant woman communicated with the phantasy organ of the child, so that any perception aroused in the mother's mind in turn reacted upon and moulded the form of the child. These beliefs remain ingrained in Maltese mentality up to present times. P Cassar, 'The neuropsychological concepts of Dr. S. Bernard', Scientia, 1949, 15: 29.
}

\footnotetext{
$26 \mathrm{~J}$ Cassar Pullicino, Studies in Maltese folklore, Malta, University Press, 1992, pp. 208-47; CEM 78B, fol. 457; CEM - A0508, op. cit., note 23 above; $P$ Cassar, 'Healing by sorcery in seventeenth and eighteenth century Malta', St. Luke's Hospital Gazette, 11(2): 79-88; C Cassar, 'Witchcraft beliefs and social control in seventeenth century Malta', $J$. med. Studies, 1993, 3(2): 316-34; Donnison, op. cit., note 9 above, pp. $4-5$.
} 


\section{The Roman Catholic Church and Midwifery Practice in Malta}

required to make a declaration of faith in the presence of the Bishop before being allowed to practise on the Islands. Furthermore, the Synodal Constitutions of 1591 and 1625, obliged Maltese doctors to persuade seriously sick patients to receive the sacraments. The doctor was debarred from visiting the patient after the third day if he had not complied with this ruling. The same conditions applied to admission to the hospital managed by the Knights of St John where no patient was assigned a bed until he had confessed his sins and received Communion. This ruling was removed by 1802 , though the hospital chaplains were bound to administer these sacraments to every newly admitted patient. Midwifery patients undergoing operative delivery in 1804 were similarly exhorted to receive them. The practice of administering the sacraments to seriously ill patients conformed to the provisions of the Lateran Council held in 1215 under Pope Innocent III. The Lateran Canon promulgated states that

Foreasmuch as the soul is far more precious than the body, we do prohibit under pain of anathema, that no physician for the health of the body shall prescribe to a sick person anything which may prove perilous to the soul. But when it happens that he is called to a sick person, he shall first of all effectually persuade him to send for the physicians of the soul; that after the sick person hath taken care of his spiritual medicament, he may with better effect proceed to the cure of his body.

The practice related to the ancient belief that sickness was the result of sin and thus the patient had to enter a state of grace before undergoing treatment. ${ }^{27}$

The belief that sickness and suffering were a consequence of sin also affected the parturients' concept of the suffering experienced during childbirth. In 1804 the pains of labour were considered an inevitable accompaniment of childbirth, an attitude perpetuated by the Church on the basis of the statement "In sorrow thou shalt bring forth children" (Genesis 3:16). Thus in his lecture notes to Maltese medical students, F Butigiec commented:

Owing to the sin of our first parents, God condemned woman to bring forth her children in pain; and the art does not have sufficient means to prevent it ... while God has ordained that woman should face the dangers of pregnancy and labour . . . as a punishment for having eaten the forbidden apple, He has, through the study of the anatomical structure and physiological mechanisms involved in child-bearing, provided us with the means of assisting her in her trying situation.

Analgesia for operative midwifery procedures was apparently in use locally at least by the end of the nineteenth century when morphine was reportedly given as an analgesic in cases requiring intra-uterine manipulations. Morphine was earlier reported in the management of cases of severe puerperal sepsis, while opium extract was described as useful in 1871 in cases of eclampsia. After its introduction for surgical anaesthesia in Malta in 1847, chloroform was used to induce anaesthesia in cases of eclamptic convulsions in 1871 and for those requiring intra-uterine obstetric manipulations in $1890,{ }^{28}$ long after chloroform analgesia for normal labour had been introduced in

\footnotetext{
${ }^{27}$ Cassar, op. cit., note 20 above; Guy, op. cit., note 16 above, pp. 530-1.

${ }^{28}$ Butigiec, op. cit., note 20 above; G F Inglott, 'Distocia', La Rivista Medica, 15 April 1890, Anno
}

I(3): 6; S Arpa, Di un caso particolare di gravidanza extra-uterina, Malta, P Camilleri, 1843, pp. 16-17; G Gulia, 'Ostetricia. Sulle convulsioni puerperali', IlBarth, 16 October 1871, Anno I(3): 45-8. 


\section{Savona-Ventura}

Edinburgh by Sir James Young Simpson in 1847. The introduction of this method of pain relief during labour elicited strong objections in both ecclesiastical and medical circles in England, so much so that it was only after Queen Victoria accepted it from John Snow at the births of Prince Leopold in 1853 and of Princess Beatrice in 1857 that opposition began to subside. There seems to have been no echoes of this controversy in Malta, probably because analgesia for normal obstetric cases was not introduced during the early years of inhalation anaesthesia. ${ }^{29}$

After the delivery, particularly if it had been prolonged and complicated, the parturient felt obliged to offer thanksgiving to particular saints associated with childbirth. The external form of this thanksgiving included the "ex-votos" found in various churches on the Islands. These took the form of silver representations of swaddled newborn infants or paintings depicting childbirth. One painting dated 1826, found in the church dedicated to Our Lady of Delivery in Malta, portrays the safe delivery of quadruplets. A number of saints have been associated with childbirth on the Islands. The intervention of Christ's mother is frequently solicited. Other favourites include St Lukarda, St Blaise, St Raymond Nonnato, St Spiridion, St Calogero, St Victor, and St Peter Martyr. While the donation of "ex-votos" to churches is no longer regularly practised, parturient mothers still exhibit their gratitude for being safely delivered by distributing printed images of the saint whose intervention was solicited. ${ }^{30}$

\section{Marital Relations}

The influence of the Church extended to various aspects of social life in Malta. The Catholic Church has always considered that marriage was not a personal affair which could be conducted privately by the partners, but a social and religious contract which fell under its sole jurisdiction. This principle was strictly adhered to even during the nineteenth century when mixed marriages with Protestant residents became a possibility. Such marriages required the Church's dispensation which bound by oath the Protestant party to bring up any issue in the Roman Catholic faith. The Roman Catholic rite remained the only legal form of marriage on the Islands until the introduction of civil marriage in $1975 .{ }^{31}$ With an absolute control over matrimonial matters, annulments fell under the jurisdiction of the Ecclesiastical Court. Children were the prime reason for marriage, and marriage without children was unthinkable. While suits for annulment were rare, two justifications accepted by the Church authorities were infertility and impotence. In 1542 a case for annulment was considered by the ecclesiastical tribunal. The plaintiff based her petition on the fact that her spouse suffered from a defect in the configuration of his "virile member". The Ecclesiastical Court nominated two medical doctors who came to the conclusion that the abnormality (hypospadias) was not inducive

\footnotetext{
29 M Simpson, Simpson the obstetrican, a biography, London, Gollancz, 1972; J A Shepherd, Simpson and Syme of Edinburgh, Edinburgh, Livingstone, 1969, pp. 98-100; P Cassar, 'The history of anaesthesia in Malta', Acta Anaesth. Melitensis, 1984, 1(2): 13-18.

${ }^{30} \mathrm{C}$ Bianchi and P Mizzi, 'Wayside chapels: TalHlas in Qormi', Heritage, undated (1984), 57:
}

\author{
1129-35; Cassar Pullicino, op. cit., note 26 above, \\ pp. 217-21. \\ 31 Ciappara, op. cit., note 3 above; A V Laferla, \\ British Malta: vol. I - 1800-1872, Malta, Aquilina \\ Publishers, 1976; Iz-Zwieg civili f'Malta. Kummenti u \\ Documenti dwar il-Ligi taz-Zwieg, Malta, Cana \\ Movement, 1978.
}




\section{The Roman Catholic Church and Midwifery Practice in Malta}

of "generating and begetting children", and the court ruled that the marriage was null and void. ${ }^{32}$ A similar case was brought before the Ecclesiastical Court in 1756 . The husband was examined by four doctors, who decided that his genitalia were more than sufficient to enable coitus. ${ }^{33}$ Impotence and infertility caused by the absence of reproductive organs remained valid reasons for annulment even in the civil law introduced in $1975 .^{34}$

Eighteenth-century midwives were on occasion requested by the Ecclesiastical Court to confirm a woman's virginity. In 1764 a midwife was appointed by the Court to examine a 17-year-old girl to confirm violation. A midwife was also duty bound to make the mother of an illegitimate child name the father, in order that he might not evade his duty to maintain his offspring, nor escape the punishment that could be inflicted for his offence in fathering it. In 1783, a midwife swore before the Bishop's Court that a newborn illegitimate child resembled the named father. He was fined by the Court and made to pay for the expense of the delivery and to contribute to the child's upkeep.

The problem of illegitimacy in the Maltese Islands is a perennial one. Historical evidence of the concern it caused dates back to the sixteenth century with the provisions made at Santo Spirito Hospital for the care of abandoned foundlings. During the second half of the eighteenth century, the illegitimacy rate on the Maltese Islands averaged about 4.7 per cent of total baptisms. This fell to about 1 per cent of total births at the turn of the twentieth century as a result of puritanical attitudes towards sexual behaviour and the stance of the Roman Catholic Church which considered promiscuity a sin which merited excommunication. Young women found to be pregnant were urged by their family and the Church authorities to get married. The role of midwives in marriage annulment proceedings was initially codified by Pope Gregory IX in 1220. Midwives' testimony was considered important in paternity cases, and in those dealing with the performance or non-performance of marital functions, and the identity of children. The use of midwives as expert witnesses, sometimes in preference to physicians, was widespread in fifteenth-century Europe. ${ }^{35}$

Marriage was only for procreation and not for recreation, and all sexual acts which did not result in the insemination of the woman were considered to be venial sins, while the Council of Trent (1545-1563) urged couples to abstain from sexual acts at least three days before Communion and more frequently during the period of Lent. ${ }^{36}$ Contraception in any form was prohibited. Abnormal intercourse of various kinds was probably practised regularly. The Augustinian friar, Fr Gesuardo Agnelli, made a point of asking his Maltese women penitents whether their husbands had unnatural intercourse with them. ${ }^{37}$

Throughout history there has been a desire to control conception. In Europe up to 1650 , there was an ecclesiastical prohibition against contraception based on Aquinas' view that "in so far as the generation of offspring is impeded, it is a vice against nature

\footnotetext{
32 P Cassar, 'A medico-legal report of the sixteenth century from Malta', Med. Hist., 1974, 18: 354-9.

33 AAM, 'Super divortio inter Alicunda Vella e Alessio Vella', unclassified documents; Ciappara, op. cit., note 3 above, p. 69.

34 Act. No. XXVII, 1975.

35 CEM, AO696, fols. 286r-367r; CEM, AO672, fols. 153r-188v; Ciappara, op. cit., note 3 above, $p$.
}

\author{
31; C Savona-Ventura, 'Illegitimacy in the Roman \\ Catholic community of Malta', Planned Parenthood \\ in Europe, 22(2): 30-2; R E McGrew, Encyclopedia \\ of medical history, London, Macmillan Press, 1985, \\ pp. 203-4; T G Benedek, 'The changing relationship \\ between midwives and physicians during the \\ renaissance', Bull. Hist. Med., 1977, 51: 550-64. \\ 36 Ciappara, ibid, pp. 63-75, 90. \\ 37 AIM - Processi 131 A, fols. 155r-207r.
}


which happens in every carnal act from which generation cannot follow". Because of this, the only contraceptive measures used were ineffective ones based on folk remedies, although to some extent coitus interruptus was practised. Mechanical methods of contraception were unknown in Europe although in 1564 Fallopius had recommended a linen covering the glans penis as a protective against syphilis. The condom, made from sheep's caecum, was advertised widely as protection against syphilis in London between 1750 and 1820 . By the last decade of the eighteenth century, the cultural climate in Europe, together with the diminishing ecclesiastical dominance in sexual matters, increased the interest in conception control. By 1860 in England, it was considered safe to write about contraception, while the first family planning clinic was opened by $\mathrm{Dr}$ Aletta Jacobs in Holland in 1882. The independent work of K Ogino in Japan and H Knaus in Austria in the 1930s showed that the timing of ovulation was relatively constant with respect to the onset of the next menses, thus allowing the beginning of "rhythm" as a valid contraceptive method.

Concerned about the increasing use of various forms of birth control, Pope Pius XI in his encyclical on Christian marriage Casti connubii in 1930, described the use of contraceptives as being against natural law, though he declared that this did not apply to the so-called "safe period". The stand taken on birth control in that encyclical has never been revoked by the Church and has been repeatedly restated by subsequent papal encyclicals. Artificial methods of birth control not accepted by the Roman Catholic Church include either the voluntary interruption of the sexual act or the use of mechanical devices, antiseptic chemicals, hormonal drugs, and surgical sterilization. The use of these methods is lawful in certain pathological conditions where the aim of the therapy is not to avoid pregnancy, but to overcome a physiological disorder (principle of double effect). These teachings remain in force, and the Maltese ecclesiastical authorities have in recent years felt the need to restate the Church's teaching on methods of birth control, especially after the introduction of state managed family planning clinics in 1982 following pressure by a secular women's group Nin-naha tan-nisa. In these clinics all methods of contraception were promoted and made available. ${ }^{38}$

In the late 1950s a survey carried out among Maltese married couples showed that while 82 per cent knew of the existence of the rhythm method of contraception, only 27 per cent understood how to use it. Subsequently, in 1962, the Maltese Church introduced family planning clinics under the direction of the Cana Movement. In the first two years of operation, these clinics dealt with over 1,325 cases. The Cana Movement also published a number of information booklets on the rhythm method of contraception. ${ }^{39}$ In a 1971 survey of 321 women under 45 years of age, 87 per cent said they used some form of contraception. About a quarter of those practising contraception used the rhythm method alone, the remainder using methods not approved by the Church, with coitus interruptus being the most common. ${ }^{40}$ The trend apparently changed in the subsequent decade. In a survey of 5,286 puerperal women giving birth in 1983 , only 8.6 per cent

${ }^{38} \mathrm{D}$ Llewellyn-Jones, Human reproduction and society, London, Faber and Faber, 1974, pp. 225-43; Quin, op. cit., note 10 above, pp. 109-10; Anon., 'Change of heart in Malta', People, 1982, 9(1): 31-2.

${ }^{39}$ A Gerada, A Galea, F F Fenech (eds), The Catholic doctor and his apostolate within the family. Proceedings of the First European Congress of
Catholic Doctors, Malta, Medical Association of Malta, 1966, pp. 171-5; M Eminyan, Il-Mizzewgin u lippjanar tal-familja, Malta, Cana Movement, 1973; E

Licari, L-ippjanar naturali tal-familja, Malta, Cana Movement, 1976.

${ }^{40} \mathrm{R}$ G Milne, 'Family planning in Malta', Population Studies, 1973, 27(2): 373-86. 
stated that they did not plan to use any form of contraception, while 11.8 per cent planned to use the natural method as recommended by the Roman Catholic Church. Coitus interruptus was the method chosen by 59.2 per cent of women, while hormonal intervention was planned by 5.5 per cent. A similar 5.4 per cent planned to use the IUCD, and 6.2 per cent barrier/foam methods. The remainder opted for sterilization with 1.2 per cent being sterilized at Caesarean section. ${ }^{41}$

The change in attitudes towards contraception is the result of the accelerating process of secularization which has influenced ideas about marriage and human procreation. A population study showed that 34 per cent of participants ready to obey ecclesiastical authority agreed with the use of artificial contraceptives, as opposed to 68 per cent of persons who did not accept ecclesiastical authority. Similar trends were shown in the case of abortion ( 28 per cent versus 54 per cent). The process of secularization was also evident in many other developed countries. The use of the rhythm method of contraception declined sharply during the 1960s in the developed countries when many women, both Catholic and non-Catholic, chose oral contraceptives in preference to periodic abstinence. In the USA, the use by Catholics of the rhythm method declined by 54 per cent in 1955 to 28 per cent in $1965 .^{42}$

The Church's objection to the promotion and use of the condom remains unchanged even in the light of the AIDS epidemic of the last decade. The Maltese Church authorities have objected to the promotion by the Health authorities of this form of contraception as a protective measure against the possibility of infection with the HIV virus. ${ }^{43}$ The objection of the Church to sterilization has similarly influenced its use in the state hospitals where it is performed only for cases with a medical complication and is not freely available for family control, while the service of IUCD insertion in the state's family planning clinics, introduced in the 1980s, was suspended in 1993 following a concerted outcry in the local newspapers by pro-life individuals. The Government authorities and the appointed Bioethics Consultative Committee allowed this campaign to influence its decisions and to override the advice of its medical advisors, the Malta College of Obstetricians and Gynaecologists, and other individuals who joined the debate in the press. ${ }^{44}$

\begin{abstract}
Abortion
Another controversial method of controlling family size is abortion. Roman Catholics accept the moral imperative that one should not kill an innocent human being. Much discussion has centred around the moment of ensoulment of the fetus, but traditionally Catholics hold that the soul enters the zygote at the moment of conception, although this

41 'Storky Maternity File-1983', Department of Obstetrics and Gynaecology, Karin Grech Hospital, 1983, unpublished computer data.

${ }^{42} \mathrm{C}$ Tabone, The secularization of the family in changing Malta, Malta, Dominican Publication, 1987, p. 163; C Ross and P T Piotrow, 'Periodic abstinence', Population Report, June 1974, ser. 1, no. 1.

${ }^{43}$ D Caruana Galizia, 'Keeping the lid on the spread of AIDS', Sunday Times [of Malta], 12 September 1993, p. 27.

\footnotetext{
${ }^{44}$ Malta College of Obstetricians and Gynaecologists, The mode of action of the intrauterine contraceptive device, Malta, 1993; J Bonnici et al., Sunday Times [of Malta], 28 February, 14 March, 28 March, 4 April 1993; J A Cannataci, 'Logic and contraception', Sunday Times [of Malta], 18 July 1993, and subsequent follow-ups; Bioethics Consultative Committee, The mechanisms of action of intrauterine devices: ethical considerations, Malta, 1994.
} 


\section{Savona-Ventura}

has been Roman Catholic dogma only since 1869. Before that the majority of Roman Catholic moral theologians believed that ensoulment occurred when the conceptus had a human form. The anti-abortion stand of the Roman Catholic Church was restated in the Papal Encyclical Humanae vitae in 1968. Protestant theologians differ considerably, but most are more liberal than Roman Catholics. In 1962 the British Council of Churches decided that biological life became human at nidation not conception. ${ }^{45}$

Pregnancy termination remains illegal in Maltese civil state law, thus it conforms with the Roman Catholic Church's teachings which are based on the sanctity of human life. But illicit termination of pregnancy has been long practised on the Maltese Islands, though repeatedly condemned by the Maltese ecclesiastical authorities. The Synod of 1703 warned the faithful that abortion was a sin that could be pardoned only by a bishop (as it still is), while in 1786 Archbishop Labini reminded them that abortion was murder and incurred the penalty of excommunication. Persons who could be considered guilty of abortion included not only those who maliciously obtained it, but also cruel husbands who ill-treated their wives and careless mothers who performed heavy work during pregnancy, or went on long walks or to dances, or did not take food, or were indiscreet in their fasts. Parish priests were to urge their parishioners to give alms to poor pregnant women to enable them to buy necessary food or medicine. Anyone knowing somebody who was to have an abortion was encouraged to report the matter immediately, while those women who were afraid for their good name were to go secretly to their parish priest who would give them every help and consolation. ${ }^{46} \mathrm{~A}$ number of cases of abortion appeared before the Inquisitional Tribunal and the Bishop's Court in the seventeenth and eighteenth centuries. None of these cases apparently involved midwives or medical practitioners. One case involved a chemist. ${ }^{47}$

The Roman Catholic Church's concept of the sanctity of life brought on a related controversy regarding the mode of delivery in cases of obstructed labour. During the nineteenth century there was a widespread desire amongst obstetricians to avoid craniotomy in cases of women with contracted pelvises. This resulted in the increasing acceptance of Caesarean section and symphysiotomy in spite of the high maternal mortality and morbidity of these procedures. These alternatives to craniotomy initiated a medico-moral dispute between Catholic and Protestant medical schools of thought, the former favouring the infant and the performance of Caesarean section or symphysiotomy, while the latter favoured the mother and the performance of craniotomy. In 1888 the Roman Catholic Church decided that the destruction of the child in utero was not permissible under any circumstances. This pronouncement was repeated with papal approval in 1895. The European controversy of craniotomy versus Caesarean section continued up to the early years of the twentieth century, and was only resolved with the increasing safety of Caesarean section. ${ }^{48}$

45 Llewellyn-Jones, op. cit., note 38 above, pp. 315-17; B Haring, Medical Ethics, Slough, St Paul Publications, 1991, pp. 90-112.

46 Synodus ..., op. cit., note 11 above; AAM, 'Edicta Labini', op. cit., note 18 above; Pelagio, ACM, Misc. 56, 'Dissertazioni parentiche intorno l'istituzione ed essenza, qualità, uso, e pratica della virtu della continenza del sacramento del matrimonio', fol. 62r-95v; Ciappara, op. cit., note 3 above, pp. 88-90.
47 AIM, 'Criminalia: 1644-1648', unnumbered; AIM, 'Processi 127B', fols. 1181r-1205v; AIM, 'Processi 136A', fols. 188v-189r; AIM, 'Processi 125C', fols. 1203r-v; AIM, 'Processi 135B', fol. 597r; CEM, AO696, fol. 286r.

48 A E Chisholm, 'Symphysiotomy, craniotomy, and Caesarean section, Lancet, 1923, ii: 276-8; M Chinigo (ed.), The teachings of Pope Pius XII, London, Methuen, 1958, pp. 17-90. 


\section{The Roman Catholic Church and Midwifery Practice in Malta}

To a lesser extent, these two views were evident in Roman Catholic Malta. The first mention of them was made in 1804 by Dr Butigiec, who appears to have been much influenced by French medical ideas, although he was also conversant with British authors. He was strongly in favour of Caesarean section and symphysiotomy, though he did include a number of embryotomy instruments in his armamentarium. He commented that "thanks to the sound knowledge obtained from modern anatomical studies and confirmed by authoritative rational observations, many unfortunate mothers have been saved from the cruel jaws of death together with their babies". The advances showed

how barbarous were the precepts of past obstetricians who taught that in an impossible delivery the life of the mother was to be spared in preference to that of the fetus . . . without considering the availability of the means, gained by experience, leading to the conservation of the lives of the two individuals. ${ }^{49}$

During the nineteenth century in Malta, medical thought veered towards British medical practice. In 1880, G F Inglott discussed, from a medical and moral point of view, the management of difficult labours and the merits of abortion, induction of premature labour, embryotomy and Caesarean section. He strongly advocated the last operation, emphasizing that it allowed for the survival of both mother and child. The discussion was taken up by his contemporary B Camenzuli, who promoted craniotomy and embryotomy rather than Caesarean section. In $1883 \mathrm{~S}$ L Pisani commented that the Caesarean operation could be performed as a last resort on a live woman as an alternative to embryotomy. The first recorded Caesarean section on a live woman in Malta was performed in 1891 by G B Schembri. ${ }^{50}$

\section{Modern Reproductive Technology}

The advances in investigative technology and the possibility of prenatal diagnosis and intervention have introduced new modern medico-moral controversies which need to be addressed by the Roman Catholic Church. The Church considers prenatal diagnosis to be morally licit if the process respects the life and integrity of the embryo or fetus and aims to protect or heal it as an individual. The process is however gravely opposed to the moral law when it is done with the thought of possibly inducing an abortion. This moral attitude and the fact that performing an abortion remains a criminal offence in Maltese Civil Law has contributed to the slow development of prenatal diagnostic techniques in the state hospitals so that only prenatal ultrasound diagnosis of congenital malformations is presently possible. ${ }^{51}$

Likewise, the advances in reproductive technology and the management of infertility has also brought other medico-moral questions to the fore. The Roman Catholic Church remains opposed to all forms of artificial fertilization. It considers that science and technology require an unconditional respect for the fundamental criteria of the moral law and therefore:

${ }^{49}$ Butigiec, op. cit., note 20 above.

50 G F Inglott, L'Aborto ostetrico nei suoi rapporti colla medicina e colla morale cattolica, Malta, A Pugliseviche, 1880; B Camenzuli, Contro-riflessioni sull aborto ostetrici, Malta, C Busuttil, 1880; Pisani, op. cit., note 6 above, pp. 104-5; G B Schembri,

\footnotetext{
'Prima operazione cesarea', Rivista di Ostetricia e Ginecologia, 1891, reprint.

51 Congregation for the doctrine of the faith, 'Instruction on respect for human life in its origin and on the dignity of procreation. Replies to certain questions of the day', 22 February 1987.
} 


\section{Savona-Ventura}

fertilization is licitly sought when it is the result of a conjugal act which is per se suitable for the generation of children to which marriage is ordered by its nature and by which the spouses become one flesh.

Thus the Church remains opposed from the moral point of view to artificial insemination and in vitro fertilization, whether homologous or heterologous. Such fertilization is in itself illicit and in opposition to the dignity of procreation and of the conjugal union, even when everything is done to avoid the death of the embryo. ${ }^{52}$ In accordance with this religious standpoint the services offered to infertile couples in state hospitals remain limited and artificial insemination and fertilization are unobtainable, although private clinics do provide them. The recent report of the Bioethics Consultative Committee restricts the use of donated sperm or ova, the freezing of human embryos, and surrogate motherhood. ${ }^{53}$

\section{Conclusion}

The Roman Catholic Church's contribution in the field of bioethics generally evoked mixed reactions, but the decrees of the Ecclesiastical authorities were often obeyed without discussion. The closed community of the Maltese population further ensured that these decrees were obeyed by medical practitioners, midwives, and the lay population. In recent decades, however, the ambivalent reaction to the Church's bioethical pronouncements has been felt more acutely because of an increasing trend towards an individualistic type of bioethics, which the Church considers a destructive influence. While some bioethical problems which were addressed throughout the ages have lost their relevance with the advances made in medicine, others have come to the fore. The conflicts created by the Church's teachings vis-à-vis scientific advances and society's expectations are strongly felt in a small Roman Catholic community like the Maltese Islands, where traditional Catholic values are in conflict with the increasing secularization of the population. The position of the Church on the Maltese Islands is now less dominant than it used to be since it has had to cede many of its powers to the State. Contemporary society, with its changes and developments, created new needs which could not be satisfied by the Church alone. However, although the Church in Malta appears to have lost some of its traditional social roles and functions, these have in fact simply taken on modern forms, which sometimes have a more effective impact. Above all, the majority of the Maltese remain practising Catholics and thus the Church on the Islands continues to lead and influence people because of its constant contact with them, and it remains a strong quasi-political force that continues to influence the decisions of the major political parties regarding bioethical and other socio-religious issues. $^{54}$

\footnotetext{
52 Ibid.

53 D Caruana Galizaia, 'Number of Maltese couples taking donor insemination increasing', The Times [of Malta], 6 November 1993, pp. 1, 44; Bioethics Consultative Committee, Report: reproductive technology: ethical and legal consideration, Malta, 1994.
}

\footnotetext{
54 G Grima, 'The role of the church in bioethics', Bioethics, responsibilities and norms for those involved in health care, ed. T Cortis, Malta, Ministry for Social Policy, 1989, pp. 17-20; Tabone, op. cit., note 42 above, pp. 148-66.
} 